\title{
THE JOURNAL OF DAIRY RESEARCH
}

\author{
EDITED FOR \\ The Committee of Management
}
BY A. T. R. MATTICK,
B.Sc., PH.D.
The National Institute for Research in Dairying, University of Reading
N. C. WRIGHT, M.A., D.Sc., Pu.D.
The Hannah Dairy Research Institute.

ASSISTED IN THE

SELECTION OF PAPERS FOR PUBLICATION

B Y

DR L. B. BULL (Australia)

DR A. D. BUCHANAN SMITH (Edinburgh)

Prof. E. P. CATHCART, F.R.S. (Glasgow)

Dr C. CROWTHER (Newport, Salop)

DR A. CUNNINGHAM (Edinburgh)

Dr PAUL FILDES, F.R.S. (London)

DR J. HAMMOND, F.R.S. (Cambridge)

DR E. C. HOOD (Canada)
DR J. O. IRWIN (London)

Prof, J. B. LEATHES, F.R.S. (Wantage)

Prof. F. C. MINETT (London)

Prof. H. A. D. NEVILLE (Reading)

Prof. W. RIDDET (New Zealand)

DR W. M. SCOTT (London)

Prof. J. A. SCOTT WATSON (Oxford)

DR P.J.DU TOIT, F.R.S.(S.A.) (S. Africa) 
PRINTED IN GREAT BRITAN 


\section{O N T E N T S}

\section{No. 1 (JANUARY, 1940)}

Original Articles:

244. The vitamin A and carotene content of Shorthorn colostrum. K. M. Henry, J. Houston and S. K. KoN . . 1

245. The partition of serum calcium about the time of parturition in the dairy cow. J. DJCKworth and W. GODDEN .

246. A long-term study of the partition of serum calcium in Ayrshire cows. W. GoDdEN and J. DUCKwORTH . .

247. The problem of variations in the growth-promoting value of milk for rats. S. BARTLETT, K. M. HENRY and S. K. KON

248. Haemolytic organism isolated from pasteurized cream. L. O'Droma.

249. Studies on the methylene-blue reduction test. II. Comparison between the old and the modified methods. T. MatuSzewSKI and J. SUPIŃsKa

250. The influence of various factors on the fermentation endproducts of the heterofermentative streptococci. C. C. THELL

251. The action of chemical disinfectants on bacteriophages for the lactic streptococci. G. J. E. HUNTeR and H. R. WHITEHEAD

252. The effect of commercial pasteurization and sterilization on the vitamin $B_{1}$ and riboflavin content of milk as measured by chemical methods. J. Houston, S. K. Kon and S. Y. THompson

253. The measurement and significance of $p \mathrm{H}$ values in cheesemaking. J. G. DAvIS and C. C. ThIEL

254. The determination of $p \mathrm{H}$ in milk and whey by means of colour indicator paper. L. SeEkLes .

Biennial Reviews of the Progress of Dairy Science:

Section C. Dairy Chemistry. S. J. Rowland and G. W. Scott Bratr 
No. 2 (MaY, 1940)

Original Articles:

255. A study of persistency in a herd of Ayrshire cows. G. PAaE Ponteconvo . . . . . . . . . 113

256. The protein requirements for milk production. S. BARTLetT, A. S. Foot, S. L. Huthnance and J. Mackintosh

257. The influence of various factors on the fermentation endproducts of the heterofermentative lactobacilli. C. C. THreL . . . . . . . . 136

258. The vitamin $B_{1}$ and riboflavin of milk . . . . 145

Part I. The application of Jansen's thiochrome test to the estimation of vitamin $B_{1}$ in milk. J. Houston, S. K. Kon and S. Y. Thompson.

Part II. The different forms of vitamin $B_{1}$ in milk. J. Houston, S. K. Kon and S. Y. Tномpson.

Part III. Effect of stage of lactation and of season on the vitamin $B_{1}$ and riboflavin content of milk. J. Houston, S. K. Kon and S. Y. Thompson.

Part IV. Comparison of chemical and biological methods of estimation of vitamin $B_{1}$. K. M. HeNRY, J. Houston, S. K. Kon and P. WhITE.

259. A note on a simple and accurate viscosimetric form of rennet test. C. W. KING and E. M. MeLVILLE

260. An objective measure of the consistency of cheese curd at the pitching point. G. W. ScotT BlaIr and F. M. V. COPPEN . . . . . . . . . .

Biennial Reviews of the Progress of Dairy Science:

Section D. The nutritional value of milk and milk products. S. K. KoN

\section{No. 3 (SePtember, 1940)}

Original Articles:

261. A study of the mortality rates of calves in 335 herds in England and Wales (together with some limited observations for Scotland). R. Lovell and A. Bradford Hill. .

262. The microbiology of silage made by the addition of mineral acids to crops rich in protein. II. The microflora. A. Cunningham and A. M. Smith 
263. The passage of carotenoids from food to milk in the cow. PAGE The fate of lycopene. A. E. GrLLAM and S. K. KoN 266

264. The effect of variations in the fat percentage and in the reaction $(p \mathrm{H})$ of milk media on the heat resistance of certain milk bacteria. A. A. NICHOLS . . . .

265. On the use of various sera for the determination of the soluble calcium and phosphorus of milk. G. T. PYNE

266. The influence of "mastitis" upon the yield and quality of Cheddar cheese. C. K. Johns, T. J. Hicks and C. A. Gibson . . . . . . . . . .

267. Studies on the chemistry of Cheddar cheesemaking. VII. The measurement of the acidity of cheese and the relation of acidity to grading score. R. M. DoLBY, F. H. McDowaLL and W. RIDDET

268. Subclinical staphyloccus mastitis in herds free from streptococcus mastitis, and its effect upon milk composition. P. M. F. ShatToCk and E. C. V. Mattick . .

Biennial Reviews of the Progress of Dairy Science:

Section E. The Diseases of Dairy Cattle. P. S. WAtTS . . 316 